\title{
Development of Website-Based a Health Crisis Reporting System
}

\author{
Yeni Rimadeni ${ }^{1}$, Hizir Sofyan ${ }^{2 *}$, Safrizal Rahman $^{3}$, Setia Pramana $^{4}$ \\ Rina S. Oktari ${ }^{5}$ \\ ${ }^{1}$ Graduate School of Mathematics and Applied Science, Universitas Syiah Kuala, Banda Aceh, 23111 \\ ${ }^{1}$ Departement of Nursing Health Polytechnic, Aceh Health Ministry, Aceh Besar, 23231 \\ ${ }^{2}$ Department of Statistics, Faculty of Mathematics and Natural Sciences, Universitas Syiah Kuala, Banda Aceh, 23111 \\ ${ }^{3}$ Department of Surgery, Subdivision of Orthopedic and Traumatology, Faculty of Medicine, \\ Universitas Syiah Kuala, Banda Aceh, 23111 \\ ${ }^{4}$ Department of Computational Statistics, Institute of Statistics, Jakarta, 13330, Indonesia \\ ${ }^{5}$ Tsunami and Disaster Mitigation Research Centre (TDMRC), Banda Aceh, Indonesia \\ *Corresponding Author: Hizir Sofyan, hizir@unsyiah.ac.id
}

\section{Abstract}

Health crisis management is prioritized on health crisis risk reduction consisting of pre-health crisis stage, health crisis emergency response stage, and post-health crisis stage. Prevention and mitigation efforts at the pre-health crisis stage, in the context of our study, aim to develop an information system for health crisis management. Information system for health crisis, in general, is provided by the Health Agency. In this study, we discussed the system applied by the Health Agency of Aceh Tengah that still uses a manual information system for reporting during disasters. Hence, it causes a delay of the information updates despite the emergency situation. To overcome this problem, we proposed a newly developed health crisis management reporting system in disaster risk reduction. We used a Research and Development approach with Heuristic Review Analysis to assess the performance of the proposed system. The scope of the study was limited to the development of a new reporting system and system test on users. The research subjects were disaster officers and heads of 14 health centers involved in the health crisis reporting in Aceh Tengah. Improvements can be made in the future through trainings and system adjustments supported by institutional policies.
\end{abstract}

Keywords: Health crisis, disasters, website, reporting system.

\section{Introduction}

Generally, health crisis management for risk reduction is carried out in three stages: pre-health crisis stage, health crisis emergency response stage and post-health crisis stage. Pre-health crisis stage aims to increase health resources, manage the threat of a health crisis, and reduce vulnerability. At the pre-health crisis stage, the activities include prevention and mitigation efforts along with preparedness. The development of an appropriate information system is necessary to overcome the health crises (Kemenkeu, 2019). When disasters such as Aceh tsunami on 26 December 2004 and earthquake in Aceh Tengah on 2 July 2013 happened, many health workers were involved in assessing the impacts of the disasters. Immediate health assessment by health officers is expected upon the occurrence of disasters.

One priority of disaster risk reduction under the Sendai Framework for Disaster Risk Reduction 2015-2030 is strengthening disaster risk management. Prevention, mitigation, preparedness, response, recovery, and rehabilitation efforts are important by establishing partnership with relevant institutions (UNISDR, 2015). These are in line with our work to develop a reporting system for crisis management for disaster risk reduction. Reporting in health crisis management is essential to retrieve a quick assessment of the impacts or possible threats on health imposed by disasters (Kemenkes, 2011). Rapid assessment methods are required to collect reliable and objective information for decisionmaking in the recovery phase (Korteweg et al., 2010).

According to Javad (2012), rapid health assessment at the time of the earthquake disaster in Azerbaijan had several problems, namely: 1) Logistical issues, 2) Insufficient tools 
to deliver information, 3) Inherent difficulty of rapid health assessment in disaster situations, 4) lack of readiness, and 5) lack of coordination among different organizations. Distribution of the information is needed in the application of rapid assessment toward the disaster victims and damages (Juhana, 2012). The presence of health workers is perceived critical in the implementation of the rapid assessment within disaster-affected areas. Poor management and database documentation are among the obstacles.

Based on our initial observations and interviews with one of the stakeholders in the Aceh Provincial Health Agency, the data input is still carried out manually during the health crisis management reporting system, causing a delay in information delivery. We further investigated the Municipal Health Agency of Banda Aceh who has ever been directly involved in handling the 2004 Earthquake and Tsunami disaster. In the agency, the implementation of the reporting system is initiated by the Public Health Center and submitted to the municipal office. Data reporting from the Health Center is then managed by staff in the outbreak and disaster section manually using the available paper form and archived as it is. The data are sent to the health service department of the Aceh Provincial Health Agency. This process actually requires fast, precise, and accurate reporting in order to optimize the crisis management, especially in handling health logistics and other assistance to the communities affected by a disaster [Kemenkes, 2009]. Therefore, we aimed to develop a reporting system for health crisis management during disasters.

\section{Method}

This research used the Research and Development approach to produce and test a particular product (Sugiyono, 2013). Spiral method proposed by Nasaruddin et al. (2013) was used, as shown in Figure 1. There were four stages in the development of the reporting system, namely concept development, application design, development and trial, and evaluation. The proposed reporting system was tested using Heuristic Review.

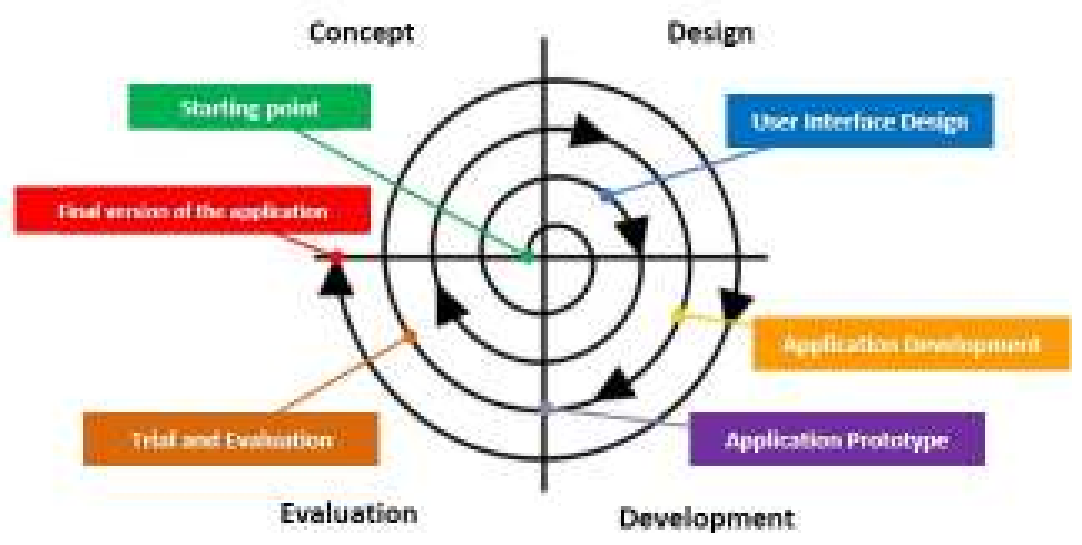

Figure 1. Spiral chart proposed by Nasaruddin et al. (2013

The object of the research was the current health crisis management reporting format. The subjects of his research were disaster officers and heads of public health centers, involved in the rapid assessment reporting systems from 11 public health centers under the Health Agency of Aceh Tengah. In total, there were 30 people who participated in the system trial, consisting of 14 RHA officers from community health centers, 14 heads of public centers, and 2 RHA officers from health agency.

The tools and materials used in this study were Network Devices for Internet Access. Hardware, such as Personal Computer (PC), Keyboard, and Mouse for interaction between 
users and the system. Softwares used were Windows and Xampp to help running websitebased applications, as well as Notepad ++ and other additional softwares. In the testing, the system was developed using Heuristic Review Questionnaire. The questions in the questionnaire aimed to evaluate whether the application suits the user's needs.

\section{Results and Discussion}

\subsection{Development Results}

Login is a part of the system security created to limit the access to the system, thus helps to improve data security and ensure the confidentiality of data from the external parties. Here is the view of the login menu from the design result (Figure 2).

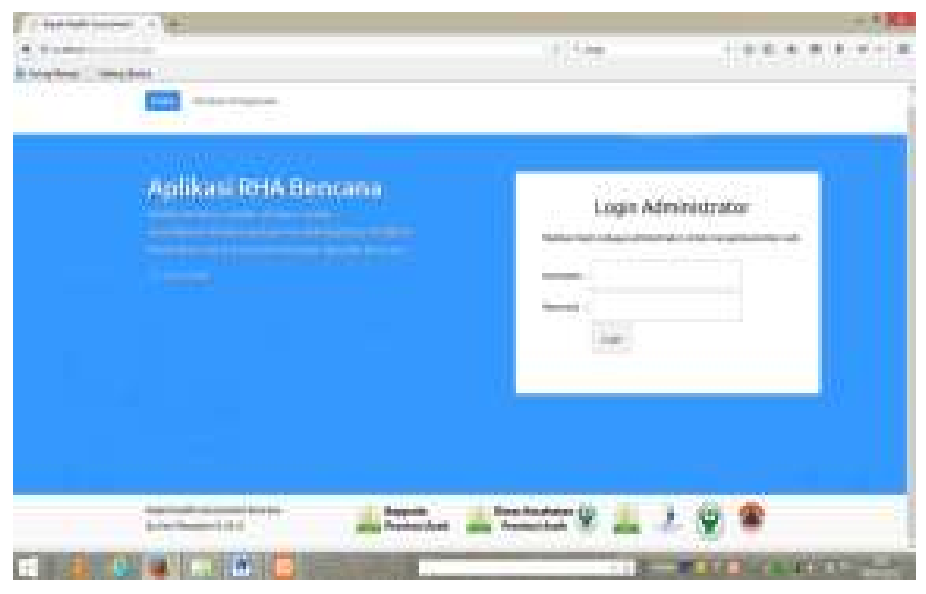

Figure 2. Login menu interface

The Main menu is the initial display when the system is first run. In the main menu, there are several options, namely initial reporting, rapid needs assessment, and disaster development. Each reporting menu has the option of adding data (entry), as shown by a sample in Figure 3.

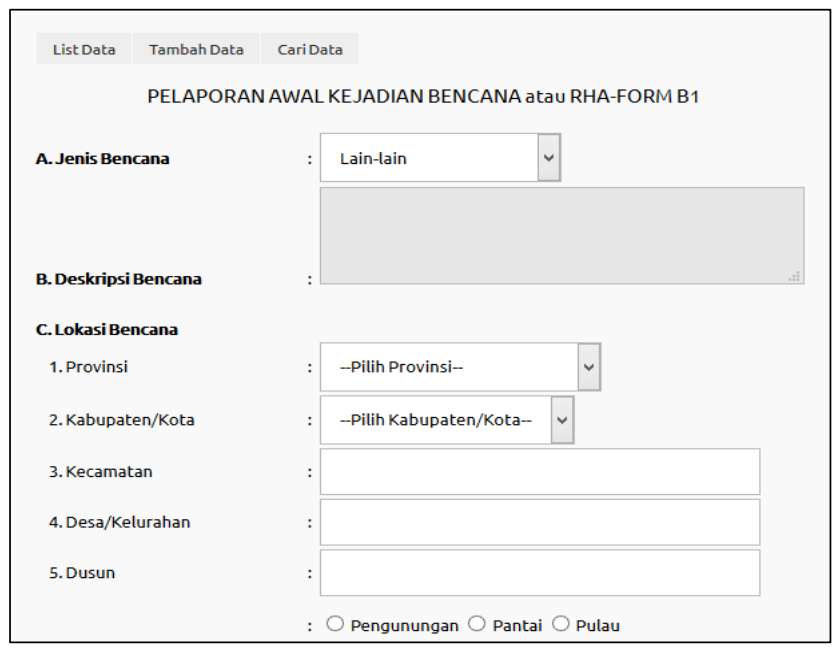

Figure 3. Display sample of add data option

The edit option is used to change the report or data that has been input. The stored data can also be deleted if it is considered wrong or unnecessary. The edit and delete views are on the same data list (Figure 4). 


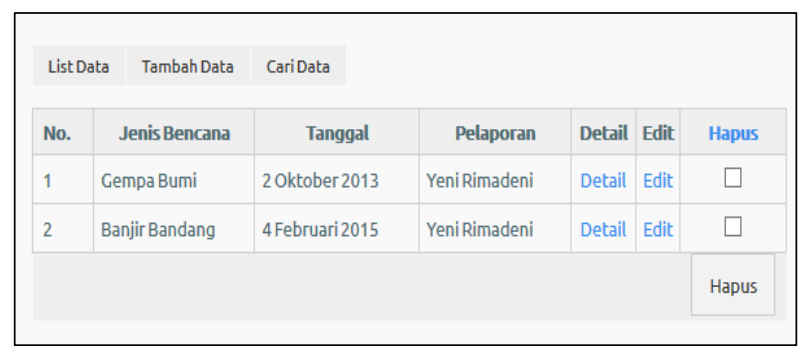

Figure 4. Features of edit and delete data options

The printing option of the report is an option that could be accessed after the data have been inputted into the added data archived in the data list. This option could be done by all levels of users (admin, user, or operator). The help menu on this web application provides information about the application and guidelines to run the reporting system.

\subsection{Steps to operate the system}

The steps in operating the system can be seen in Figure 5.

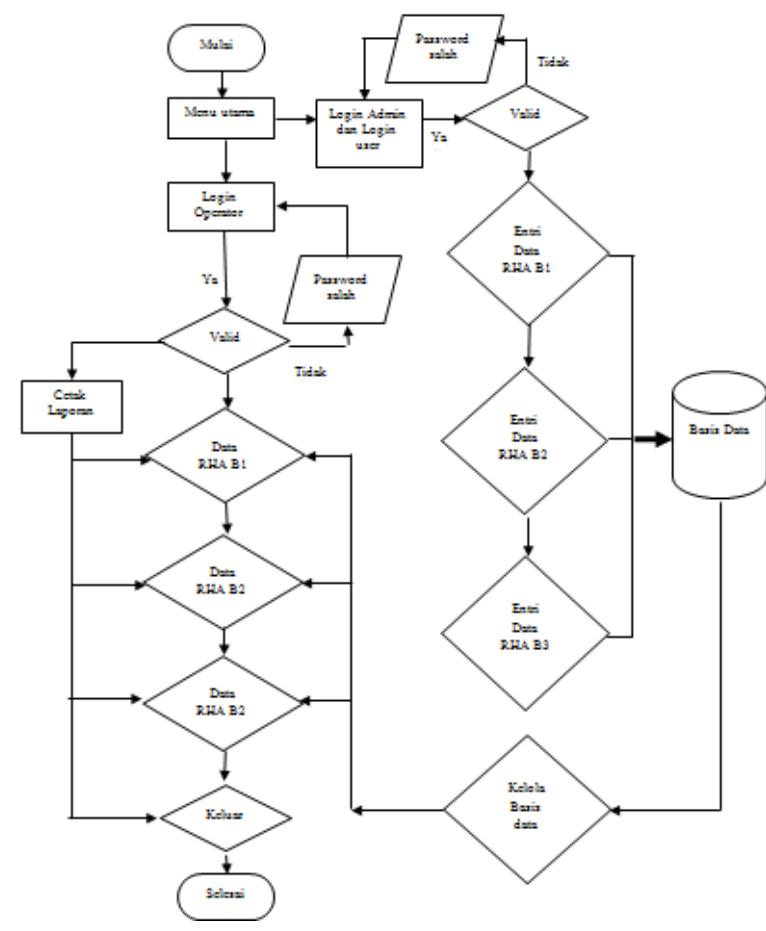

Figure 5. Flowchart of the system usage

\subsection{System Trial}

The focus of this test is to evaluate the easiness of the system operation for the manager of data and information from the reporting system, which will then be applied in the public health centers and the Health Agency of Aceh Tengah. The results of the evaluation are presented in Table 1 below. 
Table 1. Results of the trial of the newly developed reporting system

\begin{tabular}{|c|c|c|c|c|}
\hline Heuristic & $\begin{array}{c}\text { Jumlah } \\
\text { Pertanyaan } \\
(\Sigma \mathrm{P})\end{array}$ & $\begin{array}{c}\text { Kemungkinan } \\
\text { Skor }(\mathrm{K})\end{array}$ & $\begin{array}{c}\text { Skor } \\
\text { Sebenarnya }\end{array}$ & Hasil \\
\hline Desain Tampilan & 2 & 120 & 105 & $87,5 \%$ \\
\hline $\begin{array}{c}\text { Entri dan Edit Data } \\
\text { Pencarian dan } \\
\text { Informasi }\end{array}$ & 8 & 480 & 437 & $91,0 \%$ \\
\hline Fungsi Bantuan & 2 & 120 & 103 & $85,8 \%$ \\
\hline Rata-rata & 10 & 120 & 106 & $88,3 \%$ \\
\hline
\end{tabular}

The majority of participants $(87.5 \%)$ found it easy to find commands on the application interface. This is in line with Nielsen (1993), where an attractive and simple interface design and interface dialogue with relevant information are essential in an application. Furthermore, $91.0 \%$ participants felt satisfied with the data editing and deleting features. Heuristic of search and information reached $85.8 \%$ of users, suggesting an easiness in data searching according the type of disaster. Heuristic assistance function received $88.3 \%$ points, which means that users who run the website felt comfortable in searching for disaster information in the database. Figure 6 shows the results of the heuristic review in a beam diagram.

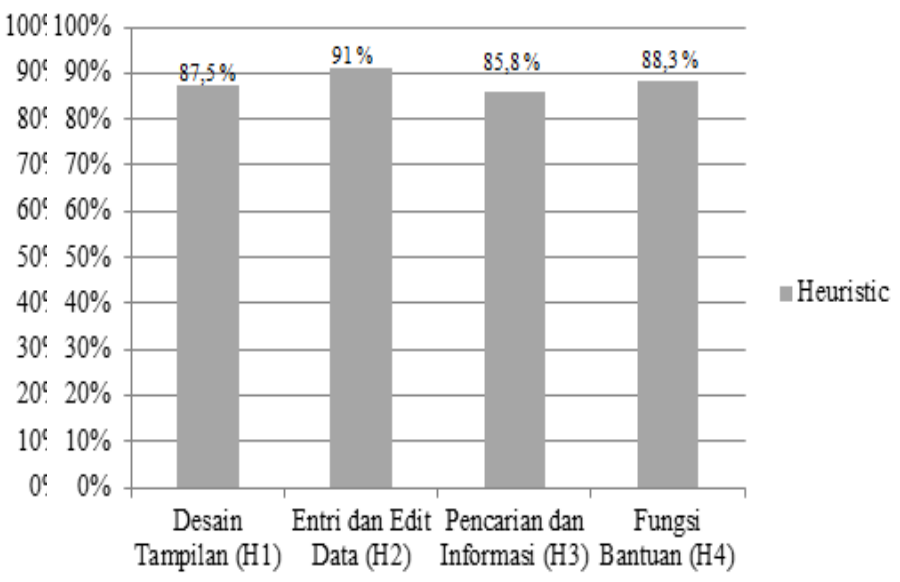

Figure 6. Trial results of the newly developed disaster website-based reporting system

\section{Conclusions}

Web-based disaster reporting systems consisting of initial disaster reporting, assessmeng of rapid disaster needs, and disaster development has been developed and run using localhost servers. This system is able to store data, display data quickly, be accessed and applied easily, and minimize the possibility of delays in the disaster reporting process, especially in Aceh Province. The results of the trial with a heuristic review method of the proposed disaster reporting system turned out to be $89.4 \%$ acceptable to the user. Thus, we recommend the addition and refinement of the web-based reporting system for disasters in terms of display design, search, and assistance functions. The newly developed system can proceed to the implementation stage, starting from training in the operation of the system for officers supported by policies from the government. 


\section{References}

Javad, B. (2012). Rapid Health Needs Assessment Experience in 11 August 2012 East Azerbaijan Earthquakes: A Qualitative Study. East Azerbaijan.

Juhana, T. (2012). Pengembangan Sistem Komunikasi Selular Darurat serta Aplikasi Kaji Cepat untuk Mendukung Pelaksanaan Tugas Tim Reaksi Cepat pada Situasi Bencana. Journal Penanggulangan Bencana, 3(2).

Kemenkes. (2019). Keputusan Kementerian Kesehatan RI Nomor 75 Tahun 2019 tentang Penanggulangan Krisis Kesehatan. Jakarta. Retrieved from https://pusdatin.kemkes.go.id

Korteweg, HA, Van Bokhoven, I., Yzermans CJ., \& Grievink, L. (2010). Rapid Health and Needs Assessments After Disasters: A Systematic Review. BMC Public Health. Jun 1; 10:295. DOI: 10.1186/1471-2458-10-295. PMID: 20515478; PMCID: PMC2889870.

Nasaruddin, N., Nurdin Y., \& Roslidar, R. (2013). The Development of Online Disaster Information System Using Location-Based Service (LBS) Technology. International Journal of Informatics and Communication Technology, 3(1), 47 58. ISSN: 22528776. DOI: http://doi.org/10.11591/ijict.v3i1.pp47-58

Nasir, M. (2011). Pengembangan Sistem Informasi Pelayanan Kesehatan Ibu dan Anak (KIA) di Puskesmas Kabupaten Lamongan. Tesis Program Pascasarjana Universitas Diponegoro. Semarang.

Nielsen, J. (1993). Usability Engineering. Boston: Academic Press.

Sugiyono. (2013). Metode Penelitian Administrasi. Bandung: Alfabeta.

UNISDR. (2015). Sendai Framework for Disaster Risk Reduction 2015-2030. Retrieved from https://www.undrr.org/publication/sendai-framework-disaster-risk-reduction$\underline{2015-2030}$ 